\title{
German beim-progressive exists: Evidence from acceptability rating and self-paced reading
}

Beate Bergmann

English Department, Humboldt University of Berlin, Germany

https://doi.org/10.36505/ExLing-2012/05/0005/000211

\begin{abstract}
This study investigates the behavior of German prepositional progressive with respect to object complementation by running an acceptability rating and self-paced reading task. Previous corpus studies showed that complements are usually incorporated when occurring with the prepositional am- or beim-progressive. In contrast, this study provides empirical evidence that German natives accept also non-incorporated complements in beim-progressive, and even more, there is a tendency towards higher acceptability of beim-progressive than the similar, even though more frequent, am-progressive.
\end{abstract}

Key words: progressive, German, complementation, acceptability rating, self-paced reading

\section{Progressive in German}

In the non-progressive language German it is possible to express progressive meaning (e.g., Bergmann 2012, Engelberg 2003) via simple present and an optionally temporal adverbial expression. Moreover, there are several lexical expressions also conveying progressive meaning.

Considering previous corpus studies on German progressive based on frequency effects, it is assumed that beim-progressives including a complement that is not incorporated tend to be ungrammatical, whereas incorporated complements are grammatical (Krause 2002, Glück 2001). In more detail, both am- and beim-structures usually do not occur with direct objects as non-incorporated complements (Krause 1997), and further, non-incorporated prepositional phrases as complements are only found rarely in case of am-progressives (Krause 2002).

\section{Methodology}

In a combined self-paced reading (SPR) and acceptability rating study ( $n=39$, German natives) it was investigated, whether the absence of a structure in a corpus is evidence enough for its nonacceptance. The current experiment implements the SPR-paradigm in combination with the method of acceptability rating by running the LINGER experimental software (Rohde 2003). More precisely, measures were taken for total reading times (RT) for complete sentences, and further, for upcoming acceptability ratings on a 1 (ungrammatical) to 7 (grammatical) scale.

ExLing 2012: Proceedings of 5th Tutorial and Research Workshop on Experimental Linguistics, 27-29 August 2012, Athens, Greece 


\begin{abstract}
Material
Due to the more investigated am-structure, and based on the assumption that the former can replace the latter (Van Pottelberg 2005), am- and beimprogressives were compared as minimal pairs both including incorporated and non-incorporated constituents. Critical items were composed on the assumption that the non-incorporated object must be realized structurally post-progressive (see Bergmann 2012 for a more detailed explanation). (1) exemplifies an experimental item for beim- and am-constructions consisting of an incorporated nominal phrase (iNP) (1a), a non-incorporated nominal phrase (nNP) (1b), or a non-incorporated prepositional phrase (nPP) (1c).
\end{abstract}

(1) a. Paul ist am/ beim Zeitunglesen.

Paul is AM/ BEIM newspaper-reading

'Paul is reading the newspaper.'

b. Paul ist am/ beim Lesen der Zeitung.

Paul is AM/ BEIM reading the genitive $_{\text {newspaper }}$

'Paul is reading the newspaper.'

c. Paul ist heute Abend am/ beim Aushelfen in der Kneipe, Paul is today evening AM/ BEIM helping-out in the pub 'Paul is helping out at the pub this evening.'

\title{
Results
}

The statistical analysis of acceptability ratings as well as reading time measures was performed via linear mixed models (Baayen 2008, Gelman \& Hill 2007). The results showed that beim-progressive forms are significantly more accepted than am-progressives $(\mathrm{t}=2.81)$ across all investigated complement types and irrespective of incorporation. Furthermore, mean rating values for both progressives with $\mathrm{nPP}\left(\mathrm{M}_{\mathrm{am}}=4.12 / 7 ; \mathrm{M}_{\text {beim }}=4.80 / 7\right)$ showed a significant higher acceptability for beim-progressive $(\mathrm{t}=2.11)$, which is in contrast to former observations (Krause 1997). Whereas mean rating values for iNP show a tendency to be higher for beim- than for the respective am-structures $\left(\mathrm{M}_{\mathrm{am}}=5.12 / 7 ; \mathrm{M}_{\text {beim }}=5.49 / 7\right)$, a marginal significant effect $(\mathrm{t}=1.78)$ is revealed for beim-progressive including $\mathrm{nNP}$ $\left(\mathrm{M}_{\mathrm{am}}=4.98 / 7 ; \mathrm{M}_{\text {beim }}=5.33 / 7\right)$.

Assuming further that longer RTs indicate greater difficulties in processing (e.g., caused by ungrammatical structures, see Sekerina, Fernández \& Clahsen 2008, Just, Carpenter \& Woolley 1982), the current data do not verify differences in processing difficulties for both progressive types. In fact, no significant differences in reading times could be found for each complement type (iNP: $\mathrm{RT}_{\mathrm{am}}=4097 \mathrm{~ms}, \mathrm{RT}_{\text {beim }}=4171 \mathrm{~ms} ; \mathrm{nNP}: \mathrm{RT}_{\mathrm{am}}=$ 
$4353 \mathrm{~ms}, \mathrm{RT}_{\text {beim }}=4543 \mathrm{~ms}$; $\left.\mathrm{nPP}: \mathrm{RT}_{\mathrm{am}}=4976 \mathrm{~ms}, \mathrm{RT}_{\text {beim }}=4196 \mathrm{~ms}\right)$. All mean rating values as well as total RTs are shown in table 1 . The corresponding plots are depicted in figure 1.
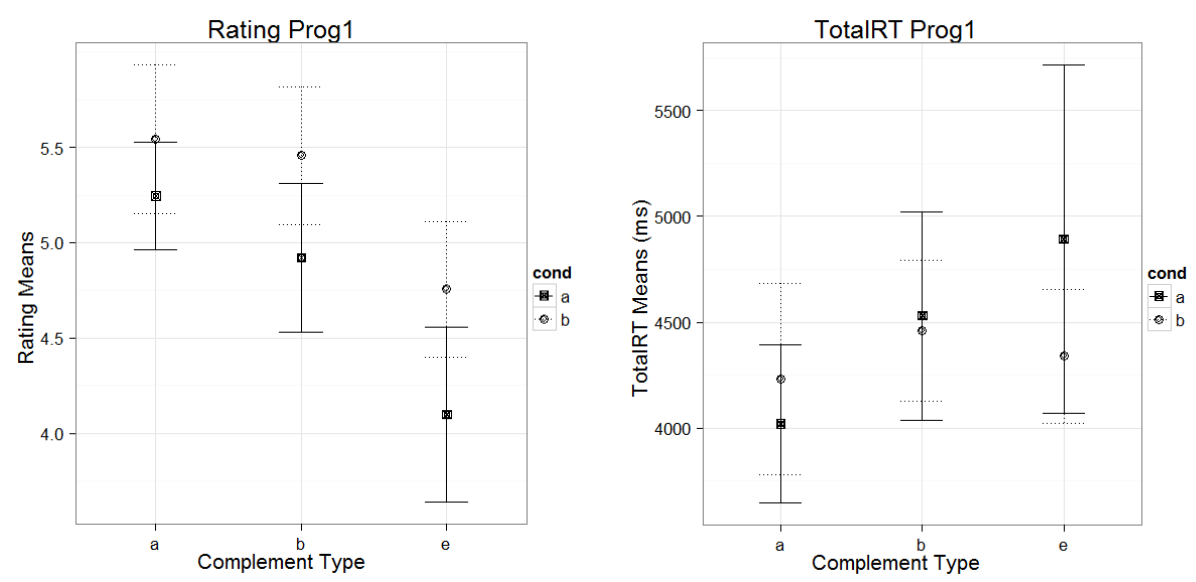

Figure 1. Mean rating measure which showed a statistical significant effect on non-incorporated complementation for nNP and nPP. Line type indicates the progressive types: solid line for am-constructions and dashed line for beim-constructions. Complement types are defined as follows: incorporated noun (a), non-incorporated noun (b), and non-incorporated prepositional phrase (e). Error bars indicate the 95\% confidence intervals. Note: Only the between-subjects variance was removed.

Table 1. Rounded rating means (numerical numbers) as well as totalRT (in $\mathrm{ms}$ ) for all six conditions, that is, the progressive type of either am or beim including the respective complement type iNP, nNP or nPP.

\begin{tabular}{|c|c|c|c|c|c|c|}
\hline \hline Condition & am iNP & $\begin{array}{c}\text { beim } \\
\mathrm{iNP}\end{array}$ & am $\mathrm{nNP}$ & $\begin{array}{c}\text { beim } \\
\mathrm{nNP}\end{array}$ & am $\mathrm{nPP}$ & $\begin{array}{c}\text { beim } \\
\mathrm{nPP}\end{array}$ \\
\hline $\begin{array}{c}\text { Rating } \\
\text { means }\end{array}$ & 5.12 & 5.49 & 4.98 & 5.33 & 4.12 & 4.80 \\
\hline $\begin{array}{c}\text { Total RT } \\
(\mathrm{ms})\end{array}$ & 4097 & 4171 & 4353 & 4543 & 4976 & 4196 \\
\hline
\end{tabular}




\section{Conclusions}

The current results suggest that beim-progressives are regardless of their complement type in the first place grammatical structures in German, contrary to former results inferred from frequency effects. In particular, the results of the present study raise serious doubts about previous claims such as non-incorporated complements are not possible with German prepositional progressive structures. Thus, acceptability in grammatical terms cannot be predicted sufficiently based on frequency in a corpus.

In sum, research on German progressive structures is still in its infancy, and therefore, further investigation needs to be done to provide a more detailed description, especially with respect to complementation and any restrictions that come with it.

The results of this study indicate a higher acceptability of beim-progressive structures in German.

\section{References}

Baayen H. 2008. Analyzing Linguistic Data: A Practical Introduction to Statistics using R. Cambridge, Cambridge University Press.

Bergmann, B. 2012. Progressive structures in German: an investigation combining self-paced reading and acceptability rating. An analysis focused on beimconstructions with respect to object complementation. University of Potsdam, Unpublished master's thesis.

Engelberg, S. 2003. The Structural Ambiguity of PPs Containing Nominalized Infinitives. Proceedings of the 2003 Conference of the Australien Linguistic Society.

Gelman , A. \& Hill, J. 2007. Data Analysis Using Regression and Multilevel/Hierarchical Models. Cambridge, Cambridge University Press

Glück, H. 2001. Die Verlaufsform in den germanischen Sprachen, besonders im Deutschen. In: Thielemann, W. \& Welke, K. (eds.): Valenztheorie-Einsichten und Ausblicke, 81-96. Münster, Nodus Publikationen.

Just, M. A., Carpenter, P. A., \& Woolley, J. D. 1982. Paradigms and processes in reading comprehension. Journal of Experimental Psychology: Genera, 111, 228238.

Krause, O. 1997. Progressiv-Konstruktionen im Deutschen im Vergleich mit dem Niederländischen, Englischen und Italienischen. In: STUF 50(1), 48-82.

Krause, O. 2002. Progressiv im Deutschen : eine empirische Untersuchung im Kontrast mit Niederländisch und Englisch. Tübingen, Niemeyer.

Rohde, D. 2003. Linger: A flexible platform for language processing experiments, version 2.94. Available at http://tedlab.mit.edu/=dr/Linger/.

Sekerina, I., Fernández, E. \& Clahsen, H. 2008. Developmental psycholinguistics: On-line methods in children's language processing, 1-27. Amsterdam, Benjamins.

Van Pottelberge, J. 2005. Der am-Progressiv. Struktur und parallele Entwicklung in den kontinentalwestgermanischen Sprachen. Tübingen, Gunter Narr. 